\title{
Dociekania
}

\section{Marcowe pisanie. O dwóch modelach przetwarzania historii}

Przemysław Czapliński

TEKSTY DRUGIE 2018, NR 3, S. 202-226

DOI: $10.18318 /$ td.2018.3.14

„[...] takie jest życie, musimy się kochać, zostały nam tylko uczucia, ponieważ świat, prawdziwy świat, już dawno przepadl"."

M arzec '68 roku trwa. Nie tylko w tym sensie, że ciągną się jego skutki, że badacze i artyści szukają winnych i kompletują listy poszkodowanych, że nadal chcą postawić przed sądem sprawców, że próbują symbolicznie zadośćuczynić pokrzywdzonym. Trwa dlatego, że nie wiemy - jak mogło dwadzieścia lat po Holokauście dojść w Polsce do ustanowienia przepisów rasistowskich, do wygnania niedobitków społeczności żydowskiej, do rozpętania antysemickiej nagonki, do wciągnięcia zwykłych ludzi w działania prześladowcze.

A skoro nie wiemy, ponawiamy pytania i kwestionujemy odpowiedzi. Spieramy się o przebieg wydarzeń i ich dzisiejsze konsekwencje, o metody badań i ich dzisiejsze implikacje. W tym sensie Marzec trwa, bo nadal dzieli:

\section{Przemysław}

Czapliński - historyk literatury XX $\mathrm{XXX}$ wieku, eseista, tłumacz; współtwórca Zakładu Antropologii Literatury (UAM Poznań). Ostatnie publikacje: Polska do wymiany (2009), Resztki nowoczesności (2011), Literatura ustna (2011), Kamp. Antologia przekładów (współredaktor A. Mizerka, 2013), Poetyka migracji (wespół z Renatą Makarską i Martą Tomczok, 2013), Poruszona mapa (2016).

1 W. Goldkorn Dziecko w śniegu, Czarne, Wołowiec 2018, s. 42. 
poglądy na temat wypędzenia Żydów z Polski w roku 1968 współkształtują preferencje i wchodzą w konflikty roku 2018. Dlatego każda opowieść o wydarzeniach Marca odnosi się do dzisiejszych powiązań społecznych. Właśnie na tym problemie skupię się w poniższym tekście. Będę badał literackie modele więzi społecznej wpisane w teksty o Marcu.

Marcowa biblioteka nie jest ani zbyt obszerna, ani wstydliwie skromna. Liczba około stu książek (a także kilkudziesięciu filmów i spektakli teatralnych, kilkuset artykułów) świadczy o tym, że problem doskwiera - boli wstecz, niepokoi w przód. Bólu i niepokoju porzucać nie wolno, ale należy je włączyć w jakiś porządek. Dostrzec go można w trzech prawidłowościach historycznych, wedle których układają się prozatorskie utwory literackie będące przedmiotem mojego omówienia: więcej, bliżej biografii, dalej od tragedii. Oznacza to, że: 1) w miarę upływu lat wzrasta liczba tekstów dotyczących Marca; 2) coraz mniejszą rolę odgrywa literatura fikcyjna, a coraz większą - literatura świadectwa (wspomnienia, pamiętniki, autobiografie, wywiady, quasi-dokumenty); 3) w Marcowym pisaniu na przełomie lat 80. i 9o. nastąpiła wymiana dominującego wzorca opowieści - z tragicznego na melodramatyczny.

W niniejszym artykule postaram się uwzględnić wszystkie trzy zjawiska, ale zasadniczo skupię się na ostatnim z nich, czyli na zmianie wzorca. Wstępnie zaznaczę, że wymiana nie polega na pojawieniu się radykalnie odmiennej wersji przyczyn bądź przebiegu wydarzeń, lecz na wprowadzeniu odmiennej koncepcji dalszego ciągu.

\section{Parabole władzy i przemocy}

Pierwszą - bardzo skromną - odpowiedzią polskiej literatury na wydarzenia marcowe była parabola. Reakcja ta miała w sobie coś z historycznej powtórki.

W ten sam bowiem sposób zareagowano dekadę wcześniej, u schyłku stalinizmu, korzystając z paraboli jako literackiej metody wyjaśniania totalitarnej wersji komunizmu. Prozaicy sięgali wówczas po wizerunki władzy absolutnej z czasów antycznej Grecji, Rzymu bądź Inkwizycji. Czesław Miłosz w Zdobyciu władzy (1952) odwołał się do Wojny peloponeskiej Tukidydesa, aby wyjaśnić konformizm intelektualistów w czasach kataklizmu i przedstawić strategię władzy opartą na postrzeganiu społeczeństwa jako zbiorowości owadziej; Hanna Malewska w zbiorze opowiadań Sir Tomasz Moore odmawia (1956) przedstawiła konfrontację renesansowego filozofa z monarchą absolutnym, sygnalizując - przeciwnie niż Miłosz - że intelektualista wierny 
swoim przekonaniom może stawić opór władzy; Jerzy Andrzejewski w powieści Ciemności kryją ziemię (1957) posłużył się figurą wielkiego inkwizytora Torquemady, wcielenia okrucieństwa i wszechwładzy świętego Oficjum, sugerując, że fundamentem totalitaryzmu był osobowy autorytet - charyzmatyczny przywódca, który bierze na siebie odpowiedzialność za zło i uwalnia ludzi od wątpliwości; Jacek Bocheński w fenomenalnej powieści Boski Juliusz (1961) cofnął się do biografii Juliusza Cezara i w narracji stylizowanej na wypowiedź przewodnika po historii starożytnej ukazał Cezara jako archetyp władcy, który wkracza na ścieżkę szaleńczego poszukiwania boskości².

Parabola włączała terror stalinowski w historię nawracających form władzy kompletnej, charakteryzując ją - za cenę uproszczeń i upodobnień - jako eksperyment socjotechniczny posługujący się autorytetem i terrorem. Odbierała więc niedawnemu okresowi jego wyjątkowość, a przy okazji pomniejszała rolę społeczeństwa, które okazywało się posłusznym owadzim rojem (Miłosz), masą spragnioną charyzmatycznego przywódcy (Andrzejewski), zbiorowością od dawna uporządkowaną w szeregach karnego wojska (Bocheński).Tylko jednostki - brat Diego z opowieści Andrzejewskiego, Tomasz Moore z opowiadania Malewskiej, przewodnik z powieści Bocheńskiego - potrafiły zdobyć się na krytycyzm i zaproponować język alternatywny do języka władzy. Ale też zajmowały one miejsce marginalne w strukturach politycznych, nie mając wpływu na podejmowanie i egzekwowanie decyzji.

Parabola stanowiła więc taktykę skutecznej regeneracji sztuki nowoczesnej. Za jednym zamachem przywracała artyście miejsce oddalone w równym stopniu od władzy i od społeczeństwa, osadzała tekst w długiej tradycji literackiej i pozwalała posłużyć się językiem wyjaśniającym historię polityczną. Wymagało to ograniczania pola odpowiedzialności sztuki: ironiczny komentator, wystarczająco mądry, by widzieć metodyczne szaleństwo przemocy, i wystarczająco słaby, by nie móc temu przeciwdziałać, opowiadał o wydarzeniach z perspektywy odosobnionego intelektualisty. Ironia stawała się taktyką tworzenia dystansu wobec masowego zaangażowania i wobec okrutnych manipulacji politycznych.

Powrót do paraboli po roku 1968 miał więc w sobie coś z odruchu popaździernikowego. W grę znowu wchodziła ranga literatury, pozycja artysty i możliwe języki oporu wobec władzy. Ale w roku 1968 kondensacja wydarzeń

2 Ze względu na ogrom literatury poświęconej tym powieściom, a także dlatego, że zmierzam ku omówieniu piśmiennictwa Marcowego, pomijam bibliografię dotyczącą wzmiankowanych powieści popaździernikowych. 
politycznych i sprzeczne formy zaangażowania społecznego (protesty studenckie vs. antysemickie zachowania ulicy) wymagały wyjaśnienia, więc nie można było usytuować się w przestrzeni ironicznego „osobno". Odruch paraboliczny mógł zatem przynieść wartościowe rezultaty pod warunkiem zrewidowania poetyki.

Tymczasem najgłośniejsza parabola pomarcowa - Msza za miasto Arras Andrzeja Szczypiorskiego - właściwie powtarzała rozwiązania z roku 1956. Powtarzała i aż do granic niezamierzonego pastiszu kondensowała. Przypomnijmy: powieść przedstawiała zarazę, która w roku 1458 pochłonęła niemal piątą część ludności Arras, oraz późniejsze wydarzenia z roku 1461, kiedy to nastąpił pogrom Żydów, a miasto pogrążyło się w amoku zabijania i rozpusty. Czarny karnawał Arras trwał trzy tygodnie i wygasł, jak zjawisko bliższe klęsce żywiołowej niż zachowaniom zbiorowym. Jakiś czas później „Dawid, biskup Utrechtu, bastard księcia burgundzkiego Filipa Dobrego - unieważnił wszystkie procesy o czary i pobłogosławił Arras"3.

Druga parabola pomarcowa, opowiadanie Wielbtąd (1973) Kazimierza Orłosia, koncentrowała się na społecznej nietolerancji. Wyjściowe wydarzenie fabularne jest ujmująco skromne: oto pewnego dnia cyrk przejeżdżający przez małe miasteczko pozostawia wielbłąda. Jeden z mieszkańców przygarnia zwierzę i od tej pory stopniowo traci wszystko: znajomych, przyjaciół, miejsce w lokalnej orkiestrze, może nawet pracę. Obserwujemy społeczeństwo, które - bez żadnych nacisków ze strony władzy - odwraca się od "zarażonego" i wypycha go poza nawias wspólnoty.

Światy przedstawione obu tekstów należą do antypodów: bogate renesansowe miasto we Francji ogarnięte szałem zabijania i rozpusty (Szczypiorski) oraz mała mieścina prowincjonalnej Polski czasów Gomułki reagująca ostracyzmem na wydarzenie spoza dotychczasowego porządku (Orłoś). Równie przeciwstawne są zachowania zbiorowe: w Mszy za miasto Arras społeczeństwo, organizując się przeciwko Żydom i czarownicom, ulega gwałtownej dezorganizacji, tak jakby przystąpienie plebsu do bezpośredniego udziału w rządzeniu z konieczności prowadziło do chaosu'; natomiast u Orłosia społeczność, jakby w obawie przed reakcją władzy, prewencyjnie zwiera szeregi i wyklucza „odmieńca", zachowując spoistość i w niczym nie zmieniając dotychczasowego funkcjonowania.

3 A. Szczypiorski Msza za miasto Arras, SAWW, Warszawa 1989, s. 5.

4 Wątki te pojawiły się w recenzjach - zob. M. Bajerowicz Rozum i sakrament, "Nurt" $1972 \mathrm{nr} 6$; T. Kotarbiński Dwa programy, "Literatura” $1972 \mathrm{nr} 2$. 
Jednakże silniejsza od różnic wydaje się kluczowa cecha wspólna - motyw kozła ofiarnego, spoczywający pod powierzchnią fabuł i napędzający wydarzenia ${ }^{5}$. Obaj pisarze, zupełnie niezależnie od siebie, scharakteryzowali dramat roku 1968 jako zrealizowany scenariusz tragicznego wykluczenia. Mechanizm kozła ofiarnego zostaje uruchomiony przez wydarzenie zakłócające społeczną akceptację nierówności w dostępie do władzy, dóbr, bezpieczeństwa i swobód obyczajowych; społeczność poddana kryzysowi wyodrębnia ofiarę, którą nakłania do wyznania win rzekomo wyjaśniających przyczyny kryzysu; ofiara upiera się przy swojej niewinności; zbiorowość zwiększa presję i przystępuje do wspólnego wykluczenia/unicestwienia ofiary. Schemat powyżej opisany będę odtąd nazywał modelem tragicznym opowieści o Marcu '68.

W świetle obu powieści wygnanie Żydów z Polski było tragedią, czyli ponurym zwycięstwem archaicznego mechanizmu kozła ofiarnego, który niegdyś więził społeczeństwa w zamkniętym cyklu zdarzeń. Cykl - zgodnie z antropologiczną i socjologiczną koncepcją René Girarda - zostaje uruchomiony przez kryzys, po którym narastają prześladowania kulminujące w zbiorowej przemocy; kiedy zbiorowość obmywa ręce z krwi, pojawia się poczucie winy, które prowadzi do ustanowienia kultu; kult upamiętnia złożenie ofiary, ale zarazem sakralizuje przemoc, więc w niczym nie narusza społecznego mechanizmu odnawiania więzi. Kiedy po jakimś czasie powraca społeczny kryzys (niezgody na własne umiejscowienie w hierarchiach władzy i zamożności), odradza się poszukiwanie rzekomych winnych, którzy staną się obiektem świętego gwałtu.

Szczypiorski i Orłoś nie pozwalali jednak domknąć się cyklowi, broniąc konsekwentnie niewinności ofiar ${ }^{6}$.Jeśli zatem pamięć Marca miałaby zostać utrwalona na podstawie tych książek, to przybrałaby ona postać kultu eksponującego niewinność prześladowanych. Było to bardzo istotną odpowiedzią na zarzuty, jakie od wojny sześciodniowej stawiano obywatelom polskim pochodzenia żydowskiego; oskarżano ich o niegdysiejsze zbrodnie stalinowskie, o wciągnięcie młodzieży do rozgrywki politycznej, o wysługiwanie się obcym państwom, o dążenie do przejęcia władzy w Polsce, o spowodowanie wielomilionowych strat gospodarczych. Lista oskarżeń formułowanych przez

5 Odwołuję się tu do oczywistego architekstu - zob. R. Girard Kozioł ofiarny, przeł. M. Goszczyńska, Wydawnictwo Łódzkie, Łódź 1987.

6 Zob. A. Tatarkiewicz Co jest prawda? , "Polityka” 1972 nr 14; B. Zadura Ratujmy nasze dusze „, "Twórczość" $1972 \mathrm{nr} 7$. 
Gomułkę, potem przez reżimową prasę (prym wiodły: „Trybuna Ludu”, „Życie Warszawy”, ,Głos Pracy”, ,Żołnierz Wolności”, ,Głos Robotniczy”, ,Gazeta Robotnicza") stanowiła zasadniczy kontekst dla literatury, która konfrontowała zarzuty z niewinnością ofiar i zakłócała doświadczenie katharsis. Być może właśnie to można uznać za umiarkowane osiąnięcie wymienionych przeze mnie dwóch dzieł: rozbuchana opowieść Szczypiorskiego i skromne opowiadanie Orłosia podważały postrzeganie Marca jako słusznej kary wymierzonej ludziom, którzy rzekomo dopuścili się przestępstw wobec społeczeństwa i państwa polskiego. Według omawianych narracji pomarcowych ofiara była niewinna. A skoro tak, to zbiorowość stawała przed alternatywą: albo Polacy zdefiniują Marcowe prześladowania Żydów jako niesprawiedliwe, kładąc kres mechanizmowi kozła ofiarnego, albo zachowają przeświadczenie o własnej niewinności i co jakiś czas popadać będą w paroksyzm zbiorowego gwałtu, który nie rozwiązując żadnych problemów, doprowadzi do kolejnego kryzysu.

\section{Po tragedii}

Tematyka marcowa powróciła do piśmiennictwa polskiego w drugiej połowie lat 8o. I przybrała nową formułę.

Zmianę można prześledzić na przykładzie kolejnego dzieła pisarza już omawianego. Andrzej Szczypiorski opublikował w roku 1986 powieść Poczatek ${ }^{7}$.W powieści - błyskawicznie docenionej przez kulturę podziemną i przez ośrodki emigracyjne, przełożonej na wiele języków obcych, wprowadzonej tuż po roku 1989 do kanonu lektur licealnych - autor przedstawił historię ratowania Żydówki Irmy Seidenman, żyjącej w czasie okupacji na aryjskich papierach i zadenuncjowanej w 1943 roku przez żydowskiego donosiciela. Solidarność sąsiadów i znajomych okazała się silniejsza od Zagłady i polskiego antysemityzmu: Irma wyszła z aresztu i dotrwała do końca wojny. Jednakże w roku 1968 zabrakło już dla niej miejsca w Polsce: w wyniku czystki antysemickiej Irma zostaje pozbawiona pracy w Ministerstwie Oświaty i zmuszona do opuszczenia kraju.

Pisarz, podważając stereotypy, których nikt chyba w połowie lat 8o. nie bronił, pokazał Żyda-donosiciela, Polaka-antysemitę, szmalcownika, zdrajcę, ale przeciwstawił temu dobre tradycje: plebejski spryt, proletariacką przyzwoitość i inteligenckie poczucie moralnej powinności niesienia pomocy. Poza tym zagrał umiejętnie na schematach pożądanych: antysemitami

7 A. Szczypiorski (1986), Poczq̨tek, Instytut Zachodni, Poznań 1989; przytoczenia ze skrótem P. 
uczynił tchórzy, przestępców albo przechrztów, zaś rok 1968, czyli akt ostatecznego wyrzucenia Żydów z Polski, przypisał wyłącznie komunistom. Reszcie społeczeństwa udzielał warunkowego rozgrzeszenia.

Warunkiem absolucji było poszerzenie pamięci zbiorowej o Żydów. Przywrócenie Żydów do pamięci potrzebne było dlatego, że powojenni Polacy - „zajęci swoimi sprawami, życiem potocznym”, gotowi byli zapomnieć o swoich sąsiadach, „nieświadomi, że zostali okaleczeni, bo bez Żydów nie są już tymi Polakami, jakimi byli niegdyś i powinni pozostać na zawsze" (P 41). Jak z tego wynika, pisarz dodawał do zbiorowej tożsamości nie tyle wspólnotę polsko-żydowskich relacji, kontaktów, zmieszanie spraw i krwi, lecz traumę po nieobecnych Innych. Istota traumy spóźnionej tęsknoty prowadziła do zrozumienia, że Polska zamieszkiwana przez Żydów była (kulturowo) bogatsza niż Polska bez Żydów. Żydzi jawili się więc jako Inni egzotyczni, tzn. jako reprezentanci społeczności, która może stanowić przedmiot fascynacji albo etnicznego zdziwienia, nigdy zaś - rzeczywistego współistnienia. Prawdziwym obiektem żałoby nie byli tu Żydzi, lecz Polacy skrzywdzeni przez totalitaryzm, który pozbawiając nas Żydów, przekształcił etniczne zróżnicowanie w jałową monoetniczność.

Wielowątkowy i rozgrywany na kilku planach czasowych utwór Szczypiorskiego nie przyznawał ani Zagładzie, ani Marcowi'68 uprzywilejowanej pozycji. Pisarz dążył raczej do tego, by przedstawić wojnę i okupację - zgodnie z tytułem - jako początek polskiego doświadczenia totalitarnego. Jednakże samo osadzenie Marca '68 w jednej linii z Holokaustem pozwala zauważyć kluczową różnicę w zachowaniach społecznych. Oto w czasie okupacji Polacy są bezsilni wobec zagłady narodu żydowskiego, ale solidarnie, na miarę swoich sił i możliwości, ratują jednego człowieka; pomocnicy, co ważne, tworzą przekrój społeczeństwa przedwojennego - jest wśród nich kolejarz, inteligent, licealista, a także „dobry Niemiec", który stanowi ostatnie ogniwo łańcucha. Wynika z tego, że w czasie Zagłady większość - bez względu na poglądy i przynależność klasową - pomagała Żydom, ustępując jedynie przed nagą siłą hitlerowskiej przemocy. Ten sposób idealizacji zbiorowości sprawił, że pisarz nie mógł powtórzyć koncepcji kozła ofiarnego z Mszy za miasto Arras; trudno bowiem byłoby przekonywać, że w czasie wojny Polacy pomagali Żydom, zaś w roku 1968 dali się sprowokować i popadli w prześladowczy amok. W ujęciu pisarza postawa społeczeństwa - coraz bardziej zintegrowanego przeciw komunistom, a zarazem, podobnie jak w czasie wojny, bezsilnego wobec przemocy systemu politycznego - pozostawała niezmieniona.Zmieniło się umiejscowienie Żydów w społeczeństwie: kiedy trwała wojna, byli 
„jednymi z nas", kiedy rozpoczął się PRL, weszli do aparatu władzy. Dlatego Irma Seidenman w czasie okupacji została uratowana, a w Marcu - osamotniona. W 1943 roku była Żydówką ściganą przez Niemców, w 1968 roku była pracownikiem Ministerstwa. Zwykli ludzie pomogli zwykłej Żydówce, zwykli ludzie odwrócili się od przedstawiciela administracji państwowej. Ubytek solidarności staje się zrozumiały, jako że Marzec jest w powieści wynikiem wewnątrzpartyjnej walki frakcyjnej, która z życiem społecznym nie miała wiele wspólnego.

Porzucenie modelu tragicznego przybliża nas do uchwycenia zmiany symptomatycznie wcielonej w powieść Szczypiorskiego. Nowy trop dostrzec można w odejściu od - charakterystycznego dla Mszy za miasto Arras - przedstawiania społeczeństwa jako tłumu tyleż destrukcyjnego, co bezwolnego, dającego sobą manipulować, przechodzącego w krótkim czasie od rzezi do apatii. Zbiorowość z Początku, przeciwnie, jest rozumna wtedy, gdy się angażuje i wtedy, gdy pozostaje zdystansowana. Racjonalność i godność wynikają stąd, że społeczeństwo jest melancholijnie oddalone od historii, którą postrzega jako arenę działania okrutnych potęg.

Zderzenie gwałtowności dziejów z melancholijnie zdystansowanym społeczeństwem przynosi ów szczególny efekt „trafnej perspektywy” i „wypośrodkowanych racji". Docenili to recenzenci tak wytrawni, jak Włodzimierz Odojewski ${ }^{8}$, Józef Łobodowski, Natan Gross ${ }^{9}$, Marek Zieliński czy Jan Józef Lipski, a jedynym wśród licznych krytyków ${ }^{10}$ prawdziwie nieufnym pozostał Jan Walc11. Recenzenci pisali o autorskiej zdolności łączenia odkrywczości historycznej ze sprawiedliwością, krytycyzmu z wyrozumiałością, pasji oskarżycielskiej z litością. Mówiąc ich słowami: Początek to „propozycja nowego, pozbawionego złudzeń i samozakłamań [... s spojrzenia na własny kraj”,

8 W. Odojewski O sprawach bolesnych z umiarem „,Puls” 1986/87 nr 32.

9 Na ostatniej stronie obwoluty pierwszego krajowego oficjalnego wydania zostali zacytowani m.in.: J. Łobodowski („Dziennik Polski”, Londyn), Natan Gross („Nowiny-Kurier”, Tel-Aviv), Marek Zieliński („Przegląd Katolicki”, Warszawa). Oprócz tego Wydawca przytoczył opinie z gazet francuskich, niemieckich, szwajcarskich oraz uzasadnienie przyznania austriackiej Nagrody Państwowej na rzecz literatury europejskiej.

Najważniejsze recenzje: J.J.L. [właśc. J.J. Lipski] „Almanach Humanistyczny” $1987 \mathrm{nr} 7 \mathrm{z} 6 \mathrm{VIII}$; J.J.L. Uczciwość, ,"brulion” $1987 \mathrm{nr}$ 1, wiosna; M. Zieliński Wstęp do epopei, „Kultura”" (Paryż) $1987 \mathrm{nr}$ 6 (przedr. "Wezwanie” $1987 \mathrm{nr}$ 12, marzec); A. Urbański Opowiedzieć spotkanie z innym, „Kultura Niezależna" 1987 nr 35, listopad); J. Łobodowski Nowa powieść Andrzeja Szczypiorskiego, "Jesteśmy" 1988 nr 2, marzec/kwiecień (przedr. z: „Tydzień Polski” 1986 nr 30).

11 J. Walc Początekżałosny, "Kultura Niezależna” 1987 nr 35. 
ale zarazem „książka przepełniona poczuciem miłosierdzia wobec własnego narodu" (Odojewski); Szczypiorski uświadamia nam, że nie mamy czystego sumienia, ale robi to w sposób, który sprawia, że „czytelnikowi łza się kręci w oku, a serce targa na strzępy, istne katharsis alla Polacca" (Chrzanowski); „przeciw schematom, nacjonalizmom i okrucieństwu napisał Szczypiorki książkę rzeczywiście bardzo piękną i bardzo mądrą” (P. Kuncewicz); „Ta książka trafia do serca i do rozumu" (N. Gross). Natomiast zgryźliwy Walc napisał: "Szczypiorski w przeciwieństwie do pana Jourdain sam nawet nie zauważa, że mówi wierszem, bo to zresztą właściwie nie tyle on sam mówi, ile raczej płyną przez niego strumienie niegdysiejszych piękności".

Retoryka dobrana przez Walca nie pozwalała wątpić, że krytyk uważa powieść za dzieło słabe. Ale mimo różnic wartościowania wskazywał, podobnie jak pozostali, na kluczowe znaczenie emocjonalnego wymiaru powieści. „Poczucie miłosierdzia”, „łza w oku”, ,serce na strzępy”, , ,katharsis alla Polacca”, "do serca i do rozumu”, ,bardzo piękna i bardzo mądra” to sformułowania, które odnoszą się do tego samego, co Walc określił jako „strumienie niegdysiejszych piękności".

Spierano się - sformułujmy ostrożny wniosek - nie tyle o uczucia, ile o ich wartość. Działo się tak nie tylko w sprawie powieści Szczypiorskiego. Jeśli na moment poszerzymy listę lektur, okaże się, że najważniejsze, a na pewno najgłośniejsze dzieła połowy lat 8o. dotyczyły traumatycznych relacji polsko-żydowskich ujmowanych właśnie od strony afektywnej. Przypomnijmy, że w roku 1985, kilka miesięcy po wyemitowaniu ostatniego odcinka brazylijskiej telenoweli Niewolnica Isaura ${ }^{12}$, publicznością polską wstrząsnął dwugodzinny (sporządzony na zamówienie TVP) skrót z filmu Claude’a Lanzmanna Shoah, że w tym samym roku ukazała się powieść Hanny Krall Sublokatorka i że w następnych latach uwagę skupiały BohińTadeusza Konwickiego, Weiser Dawidek Pawła Huellego, Zagłada Piotra Szewca, Nawrócenie Andrzeja Kuśniewicza, Teatr zawsze grany Adolfa Rudnickiego, Umschlagplatz Jarosława Marka Rymkiewicza, Kadysz Henryka Grynberga...

Niemal wszystkie te dzieła, bez względu na rozliczne różnice, są opowieściami o niespełnionym romansie polsko-żydowskim. O romansie nie tyle między pojedynczymi ludźmi, co między dwoma społecznościami, które

Znaczące wydaje się, że właśnie temu serialowi zdecydował się poświęcić jeden z tekstów Janusz Tazbir w książce przedstawiającej (skokowo i analitycznie) przemiany kultury polskiej od baroku do schyłku XX wieku - zob. tegoż Od Haura do Isaury. Szkice o literaturze, PIW, Warszawa 1989. 
nigdy się nie zmieszały. O romansie, który się zawiązywał, ale z powodów etnicznych (choć może słuszniej byłoby powiedzieć: rasowych) pozostawał zakazany. O romansie, który był faktem, a jednak nigdy nie został włączony do kultury prawomocnej i nigdy nie został zalegalizowany. O romansie, który do samego końca był traktowany jak mezalians.

Romansowa dominanta powieści i zbieżności w sposobach odbierania dzieł pozwalają zaryzykować wstępne stwierdzenie, że w połowie lat 80. w kulturze polskiej wykrystalizował się nowy język porozumienia - porozumienia poprzez emocje. Język ten wchłaniał Zagładę, Marzec'68, współżycie polsko-żydowskie w czasach zaborów i w II Rzeczpospolitej, a więc długie trwanie i raptowne cięcia, konkret historyczny i społeczne nastroje. Nie samo poszerzanie obszaru historycznego jest tu jednak ważne, lecz specyfika przyswajania dziejów. Polegała ona na przepisywaniu historii polskiej z modelu tragicznego na model melodramatyczny ${ }^{13}$. „Przepisywanie” nie oznaczało wyeliminowania tragizmu z interpretowania polskich losów. Oznaczało jedynie mocną krystalizację wzorca, który od schyłku XIX wieku konkurował $\mathrm{z}$ wariantem tragicznym ${ }^{14} \mathrm{i}$ który po przywołaniu duchów żydowskiej społeczności w latach 80. XX wieku zdawał się zyskiwać poważniejsze obywatelstwo wśród sposobów artykulacji polsko-żydowskiego doświadczenia.

Określenie "melodramatyczny” traktuję dokładnie tak samo, jak termin "tragiczny" - opisowo, a nie wartościująco. Oba nie wyczerpują możliwości interpretowania historii zbiorowej, a jednak w polskiej kulturze zdają się górować nad innymi jako najbardziej wyraziste narracje o powstawaniu i rozpadzie więzi społecznej. Istnieją między nimi fundamentalne różnice. W model tragiczny wpisane jest przekonanie, że nie ma tak spójnego społeczeństwa, którego nie dałoby się rozerwać, natomiast według modelu melodramatycznego nawet najbardziej skonfliktowane społeczeństwo można na powrót powiązać. Ujęcie tragiczne ukazuje społeczeństwo konstytuowane

Ciekawej inspiracji w tym zakresie dostarcza Anita Pluwak - zob. tejże Ambiguous Endeavours. The Evolution of the Melodramatic Mode in Polish Holocaust Narratives from Hanna Krall to "The Aftermath", "Lund Slavonic Monographs" 2015 No. 12. Autorka pokazuje, jak melodramat złożony, specyficzny dla modernizmu tryb opowiadania zwiększający swój wpływ na kulturę w epoce globalizacji - oddziałuje na polskie reprezentacje Holokaustu od lat 70. XX wieku aż do dziś. The Historical Imagination in Nineteeth Century Europe, JHU Press, Baltimore-London 1973, s. 7-11. White wyróżnia romans, tragedię, komedię i satyrę jako cztery sposoby zawiązywania akcji w dyskursie historiograficznym. 
przez łączenie pamięci ze sprawiedliwością i odmowę przebaczenia, ujęcie melodramatyczne akcentuje rezygnację z pomsty i łagodzenie reżimów pamięci. Tragedia przemienia eksces $\mathrm{w}$ historię, melodramat przekształca historię w eksces. Tragedia modeluje odbiorców jako społeczeństwo osądu ${ }^{15}$, melodramat modeluje publiczność jako zbiorowość współodczuwania.

\section{Co bóg rozłączył}

Stwierdzenie, że przebieg marcowych opowieści wprowadza czytelnika w melodramatyczne ramy, nie oznacza, że od połowy lat 80 . w polskiej literaturze powstawały wyłącznie romanse na temat roku $1968 \mathrm{i}$ że owe romanse były obliczone na tanie emocje. Melodramat nie obawia się historii. Potrafi odsłaniać złożone problemy nowoczesności, rozwiązując je zasadniczo w jeden sposób: nadaje relacjom międzyludzkim charakter rodzinny ${ }^{16}$. Oznacza to, że melodramat stawia społeczeństwo podzielone na klasy, plemiona, partie czy grupy wyznaniowe przed próbą łączliwości. W poetykę melodramatu wpisany jest eksperyment socjologiczny, który polega na sprawdzaniu warunków możliwości i warunków niemożliwości ponadplemiennej więzi.

Jeszcze raz wróćmy na chwilę do najważniejszych książek połowy lat 8o. Wszystkie one koncentrują się na konflikcie etycznym niepozwalającym powstać więzi polsko-żydowskiej, rozwijają narrację wokół obiektu erotycznej fascynacji (Irma Seidenman u Szczypiorskiego, Wieser Dawidek u Huellego, Eliasz Szyra u Konwickiego), posługują się toposem utraconej (albo nigdy nie zaistniałej) czasoprzestrzeni wspólnej. Wszystkie starają się wywołać w odbiorcy poczucie żalu, bólu, współczucia czy tęsknoty, które powinny prowadzić do refleksji moralnej i do zarysu naprawczej koncepcji etycznej.

Cechy powyższe - konflikt niszczący „rodzinę”, ośrodkowa pozycja (fascynującego i narażonego na prześladowania) Innego/Innej, marzenie o arkadii pojednanych różnic, impuls emocjonalno-moralny - stanowią kwintesencję charakterystyki melodramatu sporządzonej przez Petera Brooksa; amerykański komparatysta uznał melodramat za centralną poetykę nowoczesności

15 Zob. J.-Ch. Alexander Trauma: A Social Theory, Polity, Cambridge 2012, s. 60: „Narracje tragiczne nie skupiają uwagi na staraniach o odwrócenie sytuacji lub jej naprawę [...], lecz na naturze zbrodni, jej bezpośrednich skutkach oraz motywach i uwarunkowaniach, które do niej doprowadziły"; cyt. za: T. Łysak Trauma - od genealogii pojęcia do studiów nad traumą. [Wstęp:] Antologia studiów nad traumą, red. T. Łysak, Universitas, Kraków 2015, s. 16-17. 
(od Hugo i Balzaka, poprzez Ibsena, Dickensa i Dostojewskiego, aż do Jamesa i literatury współczesnej), stwarzając monografię, która nie tylko radykalnie zmieniła podejście do pogardzanej konwencji, lecz także wskazała nową perspektywę całościowego rozumienia dynamiki modernizmu ${ }^{17}$. Dynamika ta w odniesieniu do polskiej kultury lat 80 . XX wieku wynikała właśnie ze zderzenia tragicznego i melodramatycznego modelu opowiadania o więzi społecznej. Poszerzając wcześniejsze uwagi na temat różnic między nimi, można powiedzieć: tragedia pod powierzchnią społeczeństwa masowego widzi dawniejsze granice osobnych „plemion” (rodów, narodów, wyznań, klas), melodramat patrzy na osobne plemiona jako potencjalną rodzinę; tragedia mówi,że struktura podziału oraz zasada lojalności zawsze powracają w chwili konfliktu, melodramat - że więź może prowadzić do przekroczenia lojalności plemiennych; tragedia mówi zatem: „Co bóg rozdzielił, niechaj człowiek nie waży się połączyć”, natomiast melodramat powtarza: „Co człowiek złączył, niechaj bóg wstydzi się rozdzielić".

Melodramat, jak piszą Peter Brooks i Elaine Hadley, rozgrywa się w zdesakralizowanej nowoczesności, więc przez „boga” należy rozumieć władzę polityczną, grupę etniczną, wspólnotę wyznaniową czy jakąkolwiek inną instancję ponadjednostkową ingerującą w życie jednostek. Tacy „bogowie” mogą zdziałać tylko tyle, na ile pozwoli im społeczeństwo: mogą ostrzegać o daremności łączenia się (kolegowania, przyjaźnienia, tworzenia związku małżeńskiego) wbrew plemiennym podziałom, lecz mogą także zabraniać tworzenia takich związków, przeszkadzać im lub za nie prześladować. W modelu tragicznym Marzec ' 68 był właśnie momentem, gdy społeczeństwo odtworzyło podziały etniczne i po raz kolejny zareagowało na kryzys spoistości rytuałem kozła ofiarnego; w ujęciu melodramatycznym, rozpisanym wstępnie przez literaturę lat 8o., wina za zerwanie więzi i rozbudzenie nienawiści antyżydowskiej spadała na władzę, ponieważ społeczeństwo dysponowało już innymi możliwościami regeneracji więzi i potrafiło wyjść poza mechanizm kozła ofiarnego. Problem polegał na tym, że alternatywą dla prześladowań była obojętność.

\section{Pogrom upaństwowiony}

U schyłku lat 8o. XX wieku biblioteka poświęcona Marcowi rozrosła się gwałtownie. W rocznicowym roku 1988 ukazały się dziesiątki artykułów

17 P. Brooks The Melodramatic Imagination. Balzac, Henry James, Melodrama, and the Mode of Excess, Yale University Press, New Haven 1976. 
i kilkanaście zeszytów monograficznych rozmaitych czasopism (m.in. „Więź”, „Res Publica”, ,Krytyka”18), a na początku następnej dekady powstała pierwsza synteza - monografia Jerzego Eislera Marzec 1968. Geneza - przebieg - konsekwencje (1991) ${ }^{19}$. Publikacje te dowodziły, że nie da się zredukować Marca do pogromu Żydów i inteligentów; osadzały one rok 1968 w dramatycznym kalendarzu dekady, przekonując, że lata 1965-1967 były w Polsce okresem narastających kłopotów gospodarczych (braki w zaopatrzeniu) i czasem zablokowanej mobilności społecznej (malejące możliwości awansu, zastój płac, zahamowanie migracji ze wsi do miast, deficyt mieszkań, słabszy dopływ młodzieży wiejskiej na studia); do poważnych problemów gospodarczych i infrastrukturalnych dołączyła pełzająca rewolta ideowa, zagarniająca środowiska inteligenckiej i partyjnej elity, które domagały się rewizji socjalizmu, zwiększenia swobód obywatelskich i zniesienia cenzury ${ }^{20}$. Aby stłumić rosnące aspiracje wolnościowe i odwrócić uwagę od problemów gospodarczych, władze wykorzystały antysemityzm i antyinteligenckie resentymenty; rozkołysano emocje zbiorowe, skanalizowano je, a później zaspokojono wygnańczym spektaklem ${ }^{21}$.

Marzec zaczynał prezentować się jako wielka operacja na zbiorowości; polegała ona na tym, by wzmocnić w społeczeństwie przekonanie o braku styczności między Polakami i Żydami, a świadków przemienić we współsprawców. Był to więc eksperyment mieszczący się gdzieś między projektami Stanleya Milgrama i Philipa Zimbardo. Pierwszy z nich w roku 1961 laboratoryjnie zademonstrował skłonność ludzką do posłuszeństwa wobec

18 Tu zwłaszcza: J. Kochanowicz Czy istnieje pokolenie marcowe?, "Więż" $1988 \mathrm{nr}$; ; K. Kersten Rok 1968: motyw żydowski, „Res Publica” 1988 nr 5 (przedr. w książce tejże Polacy, Żydzi, komunizm. Anatomia półprawd 1939-1968, Niezależna Oficyna Wydawnicza, Warszawa 1992). Także: I. Krzemiński Co się wydarzyło w Marcu 68 roku?, "Powściągliwość i Praca” 1988 nr 3; A. Paczkowski 1968: Marzec kontra Maj?, Kwartalnik Polityczny „Krytyka” 1988 nr 28/29;

19 Dodać do niej należy niezbędną przy analizowaniu Marca książkę Michała Głowińskiego Marcowe gadanie: Komentarze do słów: 1966-1971, Wydawnictwo Pomost, Warszawa 1991.

20 K. Kersten Polacy, Żydzi, komunizm. Anatomia półprawd 1939-1968, Niezależna Oficyna Wydawnicza, Warszawa 1992, s. 165-166: „Kampania skierowana przeciw Żydom była instrumentem, którym posłużono się do rozbrojenia podnoszącego się ruchu wolnościowego. A także w walkach wewnątrzpartyjnych".

21 Tamże, s. 167: „Antysemickie hasła, przykrywane różnymi maskami, a powiązane z treściami populistycznymi i antyinteligenckimi, trafiały do okaleczonych warstw społecznej świadomości tym skuteczniej, że towarzyszyły im treści patriotyczne, a niekiedy wręcz przejrzyste aluzje antykomunistyczne i antyradzieckie". 
autorytetu, a więc gotowość do czynienia najgorszych rzeczy pod warunkiem, że ich żyrantem będzie wzorzec osobowy i nadrzędna idea. Dekadę później (1971) eksperyment Zimbardo potwierdził sytuacyjność moralności społecznej; badacz dodał do tego istotny czynnik, jaki stanowi osadzenie w roli społecznej. Mówiąc praktycznie: jeśli uda nam się wskazać wyrazisty cel zbiorowych działań, cel poręczany przez wysoką wartość (nauka, patriotyzm, prawda, wiara, wspólnota, jedność) i jeśli sporządzimy zestaw ról do wykonania, wówczas członkowie społeczeństwa, mimo oporów moralnych, skłonni będą zrealizować scenariusz wpisany w rolę.

Marzec '68 jawił się właśnie jako urządzony przez partię uliczny poligon rozegrany między dwoma laboratoriami. W scenariuszu zainicjowanym przez władzę, ale podjętym i rozwiniętym przez społeczeństwo, do odegrania były tylko dwie role zbiorowe: „zbyt oddalonych od (żydowskiej/inteligenckiej/ partyjnej) elity, by się angażować”22, albo „zbyt zaangażowanych (w sprawy Polski), by nie działać". Wspólnym mianownikiem w obu przypadkach był fantazmat „czystości”23. Dzięki niemu Polacy bierni mogli odizolować się od „brudnej” rozgrywki partyjnej, zaś Polacy aktywni mogli zaangażować się w „oczyszczanie” społeczeństwa.

Wspólnymi siłami partii i zwykłych ludzi przeprowadzono zatem upaństwowiony pogrom. Partia go uruchomiła, rząd zatwierdził, administracja państwowa umożliwiła, sejm i organy władzy sądowniczej zalegalizowały ${ }^{\mathbf{2 4}}$;

22 "Jestem głęboko przekonany, że w swej ogromnej większości społeczeństwo polskie pozostało co najmniej obojętne wobec tej koncepcji rozegrania wielkiej gry polityczno-społecznej [...]. Czystki ówczesne były bardzo głębokie i wyszły zdecydowanie poza aparat. Szły one, że tak powiem, aż do samego dołu. Wyrzucano, skąd się dało, kogo się dało, byle tylko był pochodzenia żydowskiego, byle tylko budził przypuszczenie, że być może jest Żydem" (J.J. Lipski Kwestia żydowska, w: Marzec '68, Sesja w Uniwersytecie Warszawskim 1981 r., Warszawa 1981, z. 1, s. 46).

Jerzy Eisler (Polski rok 1968, IPN, Warszawa 2006, s. 120) cytuje list, który podpisali "«uczciwi pracownicy Gorzowskich Zakładów Przemysłu Jedwabniczego»". Donos został rozesłany do instancji partyjnych i związkowych, milicji oraz zakładów podległych Zjednoczeniu Przemysłu Tkanin Jedwabnych i Dekoracyjnych. „Ten kuriozalny, ale w owym czasie wcale nie odosobniony dokument powstał 7 kwietnia 1968 r. Czytamy w nim m.in.: «Powszechną tajemnicą całego społeczeństwa polskiego byłfakt, że Żydzi-syjoniści rządzą w naszej ojczyźnie - zajęli wszystkie kierownicze stanowiska w aparacie partyjnym, rządowym, w nauce, kulturze, przemyśle. $\mathrm{Na}$ te tematy nie wolno nam było jednak mówić, bo zaraz przyczepiano łatkę antysemityzmu. Dziś powiało odnową, cała partia, cały naród żąda oczyszczenia się [wyróż. - P. Cz.] od Żydów-syjonistów. Proces ten przebiega jednak bardzo ślamazarnie»". konesans), "Studia Litteraria et Historica” 2017 nr 6, s. 20, https://doi.org/10.11649/slh.1486 (11.03.2018): „Ten pogrom miał obsesję własnej legitymizacji. To był «suchy pogrom», także 
istotnym uczestnikiem okazały się też media, które ogłosiły i podtrzymały antysemicką mobilizację społeczną, zapewniając komfort patriotyczny osobom niezaangażowanym. Kiedy partia uznała, że podstawowe cele osiągnięto, eksces wygaszono.

\section{Osobność}

Drobna zmiana w koncepcji Marca analizowanego przez historyków, politologów i socjologów polegała więc na tym, że antysemityzm przypisano mniejszości, zaś większość scharakteryzowano jako obojętną. O tym, co działo się pomiędzy, niewiele było wiadomo.

Właśnie tę istotną lukę wypełniła literatura lat 9o. Jeśli nieliczne dzieła wcześniejsze funkcjonowały raczej osobno, to publikacje ostatniej dekady XX wieku zatwierdziły faktyczność i ważność Marcowego pisania. Koń Pana Boga (1996) oraz Szkoła bezbożników (1999) Wilhelma Dichtera, Mezalians Violi Wein (1996), Grupy na wolnym powietrzu (1995) Eli Barbura, Krajobraz $z$ dzieckiem (1996) Romana Grena, Memorbuch Henryka Grynberga (2000) - oto lista podstawowa ${ }^{25}$. Wszystkie miały charakter wyraziście autobiograficzny, choć przybierały formy sięgające od pamiętnika (sporządzonego przez Grynberga na podstawie zapisków Bromberga), poprzez autobiograficzną opowieść (Dichter) i autobiograficzny monolog wypowiedziany (Barbur), aż po fabularyzowane wspomnienia z dzieciństwa (Gren) i cykl narracyjny na motywach rodzinnych (Wein). Późny, acz niezwykle mocny pakt autorski uzupełniał, co prawda, Marcowe pisanie o głos prześladowanych, ale uświadamiał przy okazji, że wszystko, co do tej pory wiedzieliśmy, było po większej części rekonstrukcją dokonywaną z pozycji zewnętrznych - pozycji obserwatora, badacza źródeł, postronnego świadka. Marzec '68 był więc w polskim piśmiennictwie przedstawiany i interpretowany niejako w odwrotnej kolejności: najpierw przymiarki politologiczne i historyczne, potem syntezy, a dopiero na późnym etapie - wspomnienia ludzi ze środka wydarzeń.

w tym sensie, że legitymizowany przez władzę, która właśnie przez tego rodzaju akty - na zdrowy rozum - postradała prawo do sprawowania władzy, a jednak paradoksalnie ją, iluzorycznie i na krótko, umocniła". 
Wśród tekstów szczególne miejsce zajmuje Memorbuch Grynberga - pamiętnik życia Adama Bromberga ${ }^{26}$, twórcy nowoczesnej encyklopedystyki w Polsce powojennej, który zostawił bogate materiały wspomnieniowe i dokumentalne. Grynberg skorzystał z przedwojennych podróży Bromberga po Europie, wychwytując z nich i wzmacniając pewien stały rytm. W każdym mieście europejskim Bromberg odnajdywał ślady dawnej obecności Żydów, sięgające wieku XII i stuleci późniejszych. Dzięki temu Grynberg objął swoją narracją ponad siedemset lat, ukazując cywilizację europejską jako formację, która rozwój zawdzięczała powtarzanej, lecz nieodmiennie oszukańczej obietnicy składanej Żydom. Miasta europejskie - w Hiszpanii, Francji, Niemczech, Polsce - zapraszały Żydów, korzystając z ich gospodarności, wiedzy i pieniędzy, by w momencie kryzysu (bądź nadmiernego zadłużenia) uruchamiać procedurę wykluczającą. Okresy zgodnego współżycia kończyły się nieodmiennie pogromem, gettem lub wygnaniem - którym każdorazowo towarzyszyło zagarnięcie żydowskiego mienia. Zarówno uniwersalistyczne hasła religii chrześcijańskiej, jak i równościowe idee nowoczesności, która dążyła do stworzenia społeczeństwa bez dyskryminacji etnicznej, okazywały się podszyte antysemityzmem. Z perspektywy Memorbuchu rok 1968 nie był zatem specyficznie polski ani specyficznie komunistyczny; przejawił się w nim ten sam wzór interesownego i eliminacyjnego antysemityzmu zrodzonego przez chrześcijaństwo, podtrzymanego przez kultury nowożytne i doprowadzonego do eksterminacyjnej perfekcji przez europejską nowoczesnośćn ${ }^{27}$.

Memorbuch, jak wynika z powyższego opisu, należy do modelu tragicznego. Model ten, co wybrzmiewa być może dopiero w przypadku opowieści napisanej z perspektywy ofiar, nie tylko przekreśla nadzieje na ciąg dalszy, lecz także implikuje (a może nawet postuluje) kulturowy izolacjonizm. Wydaje się to logicznym wnioskiem płynącym z myślenia tragicznego: jeśli nawet najbardziej spójne społeczeństwo można skonfliktować, wydobywając spod

26 "Adam Bromberg - dziecko bardzo zamożnej rodziny, młody komunista, więzień polityczny, zesłaniec i niewolnik strojbatu, oficer frontowy Pierwszej i Drugiej Dywizji, wybitny wydawca na skalę międzynarodową, oskarżony, więzień kliki moczarowskiej, wygnaniec - pod koniec życia nagrał na taśmach dźwiękowych i wideowych wiele gawęd o doświadczeniach swojego burzliwego życia" (Memorbuch, W.A.B., Warszawa 2000, s. 5). uprawdopodobnienia tezy o całkowitej zbrodniczości chrześcijańskiej kultury autor zaciera różnice pomiędzy konkretnymi, żydowskimi - i chrześcijańskimi - twarzami i postaciami, by ulepić dwie tylko: kata i ofiary” (Gdzie jest moja twarz?, "Przegląd Polityczny” 2001 nr 48, s. 73). 
powierzchni współżycia linie archaicznych podziałów, to jedynym rozwiązaniem pozostaje odseparowanie plemion.

Książka Grynberga posługiwała się gotowymi i skończonymi wnioskami, spójną koncepcją przeszłości i domyślną wizją pustej przyszłości. Wcześniejsze o kilka lat książki pozostałych autorów były odmienne nie tylko dlatego, że poszerzały model melodramatyczny, lecz przede wszystkim dlatego, że były wersjami do uzupełnienia. Oniryczna poetyka Grena, lakoniczność Dichtera i Vein, ciągi skojarzeniowe Barbura sprawiają, że teksty są pootwierane na wszystkie strony - w przebiegach i w zakończeniach, w prezentacji pojedynczych scen i dłuższych sekwencji. Teksty te zapraszają do wyjaśnień, odpowiedzi, uzupełnień. Są nie tyle powiadomieniem, gotową interpretacją historii, co zaproszeniem do wspólnego opowiadania. Autorzy rozwijają swoje opowieści z perspektywy niepełnej wiedzy, a w miarę rozwoju wydarzeń pogłębiają naszą dezorientację, zamiast ją pomniejszać. W rezultacie razem $\mathrm{z}$ bohaterami zanurzamy się w świat codzienny, ale pod wieloma względami niezrozumiały. Tajemnica codzienności objawia się w najprostszych sprawach i przenika całą rzeczywistość społeczną, a fabuła zamiast przynieść wyjaśnienie, doprowadza nas do momentu gwałtownego rozcięcia społecznej więzi.

Najciekawszą reprezentację owej rozmnożonej zagadki porządku codziennego napotkać możemy w Krajobrazie z dzieckiem Romana Grena ${ }^{28}$ - narracji o dziecięcym poznawaniu działania tożsamości. Narrator tej krótkiej i poetyckiej powieści doświadcza siebie i swojej tożsamości od strony różnic. Nie tyle wie, co intuicyjnie analizuje, po dziecięcemu bada, cieleśnie odczuwa. Widzi, jak w ruchach jednych ludzi na ulicach przejawia się „zdumiewająca pewność siebie: zdawali się ze sobą zrośnięci, tworzyli jedno monstrualne ciało o licznych odnóżach, które nikło w ciemnej bramie" (KZD 13); tymczasem rodzina bohatera podczas coniedzielnej wyprawy na cmentarz idzie osobno, pospiesznie, ukradkiem: „Z niewiadomego [...] powodu - spieszyliśmy się. Ojciec szedł pierwszy, ze spuszczoną głową i kapeluszem nasuniętym na czoło, za nim dreptała matka, ponaglając mnie ruchem ręki" (KZD 14). Wyraziste i jawne sygnały wyobcowania pojawiają się też w zachowaniach otoczenia. Ktoś krzyczy przez okno: „Żydzi do Palestyny!” (KZD 14), koleżanka w klasie mówi: „To wy, Żydzi, ukrzyżowaliście Pana Naszego Jezusa Chrystusa!", a kiedy syn opowiada o tym zdarzeniu ojcu, ten „strasznym szeptem"

28 R. Gren Krajobraz z dzieckiem, OPEN, Warszawa 1996; lokalizacja cytatów bezpośrednio w tekście po skrócie KZD. 
mówi: „Nigdy, rozumiesz, nigdy nie rozmawiaj z nikim o religii!” (KZD 15). W domach innych chłopców wszystko jest „na swoim miejscu” (KZD 16), natomiast $u$ nich „kąty proste nigdy nie miały pełnych dziewięćdziesięciu stopni, a nasze równoległe spotykały się za pierwszym rogiem" (KZD 16). W domu rodzinnym choinka jest, zagrożona i niepewna”, u Piotrka - „stabilna i bezpieczna" (KZD 21). A zatem inni po prostu idą, krzyczą na całe gardło, wierzą aż po nienawiść, a rodzice bohatera pilnują swoich kroków, miarkują głos, o wierze nawet nie mówią.

To „nigdy, rozumiesz, nigdy” zdradza szerszą strategię: w rodzinach żydowskich rodzice wychowywali swoje dzieci ku pełnej asymilacji. Wpisanie się w polską normalność było zasadą, która mówiła: „Nie bądź inny - bądź jak inni”. Zachowuj się normalnie, siedź normalnie, jedz normalnie, mów normalnie - oto sprawcze przywołania do porządku, który, choć nazywany normalnym, w gruncie rzeczy jest wyuczony. Podstawą normalności jest zatem performatyka - system ról i scenariuszy uruchamianych na co dzień i od święta, reguł współistnienia wyczuwanych i uwewnętrznianych, zachowań ciała i twarzy, kodów gestycznych i ubiorów, odzywek i przemilczeń. Reguły te działają pod postacią niejawną; najbardziej zastanawiającą ich cechą jest to, że nakazują postępować w określony sposób, blokując równocześnie zadawanie pytań. Spektakl normalności jest w ten sposób naturalizowany i zamienia się w treść życia. Żydzi mieli nadzieję, że staną się jak reszta, jeśli będą robili to, co inni, tak, jak inni. Warunkiem uczestnictwa było jednak powiększenie pola milczenia - czyli przyjęcie reguły zabraniającej mówić o różnicy ${ }^{29}$.

Dziecko z narracji Grena odkrywa, że w odróżnieniu od koleżanek i kolegów nie panuje nad swoją tożsamością. Rozumie, że tkwi w niej coś, co, nie będąc pod jego kontrolą, musi pozostać ukryte. Daje się więc wciągnąć w domową regułę skrytości autobiograficznej. Ani ludziom obcym, ani swoim dzieciom Żydzi nie opowiadają o własnej przeszłości, o czasach przedwojennych czy o Zagładzie. Wzmacnia tę lukę i obramowuje kompletna pustka porządków oficjalnych: Polacy i Żydzi nie obchodzili wspólnie żadnych rocznic żydowskich, a rządząca partia nie ustanowiła nowych świąt, w których

K. Kersten Polacy, Żydzi, komunizm..., s. 155: „Wytwarzał się ów patologiczny klimat, w którym sprawa związków - przeszłych lub obecnych, rodzinnych choćby - z najszerzej pojętym światem żydowskim stawała się wstydliwa, drażliwa, czasem wręcz zdrożna. Klimat zatruty tym bardziej, że świadomość przemilczanej «żydowskości» pozostawała wszechobecna i wśród komunistów, i wśród ich przeciwników, i wśród Polaków, i wśród Żydów, tyle że nie wolno było głośno o tym mówić". 
żydowskość byłaby obecna obok polskości. Żydzi biorą oczywiście udział w świętach państwowych - czcząc 1 Maja czy Dzień Zwycięstwa - ale nie jako Żydzi, lecz jako obywatele polscy. Jeśli zachowali jakieś święta własne, nie uczestniczyli w nich Polacy. We wspólnym porządku codziennym, państwowym i religijnym Żydzi więc nie istnieli. Należeli do wspólnego świata tylko o tyle, o ile ukrywali różnicę. Ich egzystencję zbiorową określała niewypowiadalność.

Kategoria ta nie odsyła do postmodernistycznej wzniosłości, która opiera się na niemożności znalezienia imienia własnego. Analizowana literatura przekonuje raczej, że w Polsce po 1945 roku doświadczenia żydowskie - a więc przedwojenne odizolowanie, Zagłada, samotność czasu wojny, lęk powojenny - uznawano milcząco za zbiór treści zakazanych. Niewypowiadalne było zatem to, czego na mocy konstruowanej po wojnie normalności nie wolno było po imieniu nazwać. Jednak Żydzi niemówiący o swojej przeszłości stawali się ludźmi zawieszonymi w historycznej próżni. Byli upiorami wymordowanej społeczności przeszłej i widmami niemożliwej społeczności przyszłej.

Damnatio dicendi, zakaz mówienia, działał do wewnątrz społeczności żydowskiej, krępując rozmowy codzienne ${ }^{30}$, i na zewnątrz, blokując autobiograficzną szczerość. Uruchamiał więc spiralę: im bardziej Żydzi mieli się nie wyróżniać, być jak inni, być tacy sami, tym bardziej zakazane było nazywanie przyczyn wcześniejszego wyobcowania, im bardziej zaś zakazane było nazywanie przyczyn, tym bardziej rosło wyobcowanie. Rację ma więc narrator Krajobrazu z dzieckiem, gdy stwierdza: „Może wszystkiemu winien był język” (KZD 20). Wspólnotowe milczenie o Żydach odkładało się coraz bardziej w języku, ale zarazem ów język zarządzał czymś więcej niż tylko samym sobą - mianowicie porządkował komunikację społeczną, przydzielał role i tożsamości, wprowadzał ład i podziały w rzeczywistość. Wymuszał asymilację bez genealogii, bez nazwisk, bez doświadczenia historycznego. Posłuszeństwo wobec tych reguł czyniło Żydów ludźmi z nicości.

Książki z lat 9o. sprowadziły więc opowieść o Marcu do poziomu życiowego konkretu, odsłaniając żydowskie życie rodzinne w stanie podwójnego oblężenia. Narzucona Żydom skrytość autobiograficzna krępowała komunikację domową i pozbawiała pełni tożsamości w komunikacji publicznej. Z wnętrza

30 "Rodzice moi mówili językiem zawiłym i niejasnym; unikali jak mogli czasu przeszłego" (KZD 18); wizyty krewnego wypełniały „milczenie, rebusy i opowieści, których bohaterami były stawy, parki, kwiaty i tylko z rzadka ludzie, bez twarzy i nazwisk" (KZD 18). 
życia rodzinnego widać też kluczową różnicę między ujęciem tragicznym $(\mathrm{H}$. Grynberg) i melodramatycznym (Gren i inni). Polega ona na tym, że model tragiczny zawiązuje wspólnotę wokół nieobecnych, model melodramatyczny - wokół obecnych. Ci obecni, jak widzimy w narracjach, wchodzą w życie społeczne: mają koleżanki i kolegów wśród nie-Żydów, zawiązują pierwsze przyjaźnie i przeżywają pierwsze miłości, tworzą pary narzeczeńskie czy małżeńskie. Wypracowali więc sieć powiązań, która okazała się silniejsza od zerwania: co prawda zostali obrzuceni antysemickimi wyzwiskami, a potem wypędzeni, ale zostawili po sobie pamięć o sztuce tworzenia więzi - wbrew podziałom wynikającym z poczucia polskiej winy i wstydu. Melodramatyczne narracje urywają się w momencie, gdy młode pokolenie Żydów właśnie miało wejść w dorosłe życie. Ale opowieści te wciągają nas nie w problem polityczny: „Dlaczego doszło do wypędzenia?”, lecz w zagadkę kolejnej szansy. Wbrew logice podsuwają pytanie, czy jest możliwe społeczeństwo po podziale. Czy jest możliwy dalszy ciąg.

\section{Marzec - reaktywacja}

Od przełomu XX i XXI wieku Marzec zaczyna funkcjonować jako swoisty ekran projekcyjny, na który rzutuje się lęki związane z aktualną rzeczywistością - lęki dotyczące groźby użycia mediów przeciw mniejszościom, recydywy nacjonalizmu, latwości propagandowego konstruowania wroga, koniecznych i niebezpiecznych związków władzy z prasąą. Ekran projekcyjny nie powoduje tendencyjności badań, zmienia jednak status samego Marca: tamten miesiąc, paradoksalnie coraz bliższy teraźniejszości, nie przestając być przedmiotem badań, staje się zarazem źródłem wiedzy o sposobach badania dzisiejszego świata społecznego. Odpowiedzi na pytania zadawane Marcowi powracają jako pytania dotyczące teraźniejszych problemów.

Nowe badania nad Marcem ukazują go więc jako moment pryzmatyczny, w którym załamaniu uległy: socjalistyczny projekt modernizacyjny, lewicowa koncepcja rewizjonistyczna ${ }^{32}$ i strategie współżycia polsko-żydowskiego.

31 Zob. m.in. Marzec '68 - szok marcowy: przegląd prasy, wyb. P. Śpiewak, Warszawa 1998; A.B. Jarosz Marzec w prasie, w: Marzec 1968. Trzydzieści lat później, red. M. Kula, P. Osęka, M. Zaremba, PWN, Warszawa 1998; P. Osęka Syjoniści, inspiratorzy, wichrzyciele. Obraz wroga w propagandzie marca 1968, Żydowski Instytut Historyczny, Warszawa 1999; D. Stola Kampania antysyjonistyczna w Polsce 1967-1968, ISP PAN, Warszawa 2000. 
Mimo poszerzania zakresu syntez „kwestia żydowska”33 zawsze powraca. W spektaklu Michała Zadary Sprawiedliwość rok 1968 pojawia się nawet jako „ostateczne rozwiązanie”34. Radykalne oskarżenie wymierzone zostało tu w systemowość prześladowań podjętych przez państwo. Nie kłóci się więc ono ze świadectwem składanym przez literaturę. Świadectwem dokładnie przeciwnym, mówiącym o roku 1968 jako „rozwiązaniu nieostatecznym”.

Świadectw jest coraz więcej i zasadniczo są one utrzymane w poetyce genealogicznej35. Od początku lat 9o. literatura nie opuszcza obszaru rodzinnego. Dzięki temu wyobrażenia o Marcu muszą konfrontować się z codziennością, jako że perspektywa rodzinna nakazuje uzupełniać każdą syntezę o pytania dotyczące rodziny, sąsiadów, znajomych, zamożności, zwyczajów domowych, szkoły, zakupów, świąt - a więc relacji między domowymi praktykami tożsamościowymi i możliwościami jej włączenia do szerszej sieci społecznej $^{36}$. Uparte trzymanie się rodziny jest w przypadku Marcowego

liczu roku 1968 jako wstrząsie dla opozycji, który sprawił, że lewica: wycofuje się z języka marksistowskiego, porzuca kluczowe pojęcia "rewolucji” i "ludu" na rzecz pojęć "społeczeństwo obywatelskie" oraz "samoograniczającej się rewolucji”, rezygnuje z kwestii ekonomicznych i klasowych, przyznaje centralną pozycję "wspólnocie narodowej”, przesuwa "lud" z pozycji podmiotowej na przedmiotową, przyznając inteligencji rolę administratora gniewu (dbającego, by gniew nie przybrał postaci nacjonalistycznej).

Zob. m.in. Oblicza Marca 1968, red. K. Rokicki, S. Stępień, IPN, Warszawa 2004 (tu m.in. D. Stola Antyżydowski nurt Marca 1968); P. Osęka Marzec '68, Znak, Kraków 2008; P. Madajczyk Cień roku '68, ISP PAN, Warszawa 2012; Społeczność żydowska w PRL przed kampaniq antysemickq i po niej, red. G. Berendt, IPN, Warszawa 2009.

34 W recenzji spektaklu Sprawiedliwość (Teatr Powszechny, Warszawa, premiera 10 marca 2018 roku, reż. M. Zadara) Edwin Bendyk napisał: „Najpierw trzeba zrozumieć, co się przed pół wiekiem w Polsce stało. To, co nazywamy Marcem '68, a co trwało w istocie od 1967 do 1971 roku, było dokończeniem nazistowskiego Endlösung - ostatecznego rozwiązania kwestii żydowskiej. Społeczność żydowska została rozbita, a tysiącletni związek Polaków i Żydów na jednym terytorium przerwany. Oczywiście, działania władz PRL nie miały charakteru eksterminacji, ale spełniają kryterium zbrodni przeciwko ludzkości - przekonują przywołani przez twórców spektaklu eksperci" (E. Bendyk Marzec '68 - tragedia sprawiedliwości, https://antymatrix.blog. polityka.pl/2018/03/12/marzec68-tragedia-sprawiedliwosci/ (23.03.2018).

35 M.in. J. Katz Moje życie barbarzyńcy (Jacek Santorski \& Co Agencja Wydawnicza, Warszawa 2006); B. Świderski Asystent śmierci (W.A.B., Warszawa 2007); H. Dasko Dworzec Gdański: historia niedokończona (Wydawnictwo Literackie, Kraków 2008); W. Dichter Lekcja angielskiego (Znak, Kraków 2010); W. Goldkorn Dziecko w śniegu (Czarne, Wołowiec 2018).

36 Zob. pionierską dla tej problematyki pracę: M. Starnawski Socjalizacja i tożsamość żydowska w Polsce powojennej. Narracje emigrantów z pokolenia Marca '68, Wydawnictwo Naukowe Dolnośląskiej Szkoły Wyższej, Wrocław 2016. 
(podobnie jak Holokaustowego) pisania związane również z realną pracą genealogiczną, a więc dokumentowaniem przodków i składaniem świadectwa o trudzie ich wyszukiwania ${ }^{37}$.

Po wtóre, Marcowe pisanie ostatnich kilkunastu lat, idąc jakby pod prąd czasu, staje się literaturą żywego głosu - mutacją historii mówionej, którą można nazwać „historią rozmówioną”. Teksty ją współtworzące - zawarte w książkach Joanny Wiszniewicz (Życie przecięte. Opowieści pokolenia Marca, 2008), Mikołaja Grynberga (Rejwach, 2017; Księga wyjścia, 2018), Krystyny Naszkowskiej (Wygnani do raju, 2017; Ani tu, ani tam, 2018) - nie koncentrują się na ustalaniu faktów, lecz na perspektywie jednostkowego doświadczenia. W odróżnieniu od oral history ${ }^{38}$, w której stawia się pytania otwarte, tu padają raczej pytania nakierowujące, ponieważ autor ma swój kwestionariusz; respondent może jednak uciekać od pytań, kwestionować je, formułować własne i w rezultacie snuć niezależną opowieść, zmierzając do „rozmówienia się" z autorem i historią, tzn. do wypowiedzenia tego, co uważa za najważniejsze. Stąd moja propozycja nazwy, jako że „rozmówienie” historii wydaje się punktem wyjścia, metodą praktyczną i celem. Punktem wyjścia, bo Mikołaj Grynberg, Naszkowska czy Wiszniewicz umawiają się z ludźmi na rozmowę o Marcu; praktyką, bo podczas spotkań Marzec staje się historią „rozmawianą", a więc obgadywaną z różnych stron, poddawaną komentarzom i interpretacjom, i pozostawianą w wersji niedomkniętej; celem, bo kiedy powstaje książka, wchodzące w jej skład dialogi nadają Marcowi charakter historii rozmówionej, czyli nie tylko mnogiej, lecz także pomyślnie przebrniętej, wreszcie wypowiedzianej, więc nieco bardziej ludzkiej, mniej obcej i nie aż tak silnie alienującej.„Marcowi ludzie” mogą mieć wrażenie, że rozmówili się z historią i z człowiekiem, a dopuszczenie do głosu ich pamięci, odczuć, wrażeń i nastrojów zwraca im cząstkę podmiotowości zabranej zarówno wtedy, gdy dział się Marzec, jak i wtedy, gdy w kolejnych syntezach ich biografie wchodzą w skład statystyk.

W statystykach tych historie rozmówione czynią sporo zamieszania w kwestii podstawowej, czyli tożsamościowej. Na pytanie „Czy wiedziałeśl wiedziałaś, że jesteś Żydem/Żydówką?", część rozmówców odpowiada: „Tak”,

Modelowy pod tym względem - opisu wyszukiwania przodków i dokumentowania samej pracy poszukiwawczej - jest autobiograficzny esej Agaty Tuszyńskiej Rodzinna historia lęku (2005). 
część: „Ależ skąd!”, a inni: „Domyślałem się, ale nic z tego nie wynikało” Po Marcu niektórzy wykształcili sobie tożsamość żydowską, inni duńską (szwedzką, amerykańską); niektórzy podkreślają, że stali się mieszańcami, inni - że nadal są Polakami. Polsko-żydowski Szwed, żydowsko-amerykański Polak, obywatel Izraela polsko-żydowskiego pochodzenia... to tylko niektóre z możliwych kombinacji powstałych pod naporem życia i za sprawą indywidualnych starań ${ }^{40}$. Stwierdzenia powyższe, sygnalizujące zagęszczenie problematyki identyfikacyjnej (od której wszystko przecież się zaczęło), pozwalają po raz ostatni omówić różnice między modelem tragicznym i melodramatycznym. W tym pierwszym człowiek zostaje wywołany do tożsamości i w niej zatrzaśnięty; tożsamość określa jednostkę, stygmatyzuje ją i stwarza ostateczne wyzwanie. Model melodramatyczny stawia na identyfikacyjną grę. Nie dlatego jednak, by ludzie wyrzekali się tożsamości w imię przetrwania, lecz dlatego, że w ramach „rozmawiania historii” bohaterowie przedstawiają (lub uświadamiają sobie, że mają) tożsamość niejasną, wieloraką, zmieszaną. Model tragiczny odsłania ludzką określoność, wyjaśniając w ten sposób narodziny konfliktów; model melodramatyczny zaczyna od konfliktu jednoznacznych tożsamości (Polak - Żyd), pokazując, że prowadzi on do przemocy albo społecznego impasu; uniknięcie dylematu „przemoc albo niemoc" okazuje się możliwe za sprawą melodramatycznego promowania identyfikacji niekonfliktowo sprzecznych ${ }^{41}$. Tak oto po trzydziestu latach od wygnania, którego przyczyna tkwiła w tragicznym rozumieniu tożsamości,

39 Zob. np. M. Grynberg Księga wyjścia, Czarne, Wołowiec 2018, s. 97, 98: „Wiedziałem [że jesteśmy Żydami], bo jak byłem mały, to fryzjer się mnie zapytał: ty, mały, jeździsz do cadyka z Góry Kalwarii? Spytałem rodziców, o co chodzi, to powiedzieli mi, że jesteśmy Żydami, i koniec tematu był. To był polski dom. Temat się pojawiał, gdy przychodził z zewnątrz [wyróż. - P.Cz.]"; s. 8: „Wiedziałem, że jestem żydem, bo ludzie tak mówili [wyróż. - P.Cz.], ale moje serce i odczucie mówiło mi, że jestem Polakiem".

40 Zob. K. Naszkowska Wygnani do raju. Szwedzki azyl, z rys. J. Helander, Wydawnictwo Agora, Warszawa 2017, wyd. elektroniczne Publio: „Czy ja koniecznie muszę mieć jakąś ojczyznę? Lubię Szwecję, lubię Polskę, dobrze się czuję w obu krajach, stoczyłem się na pozycje kosmopolityczne" (s. 85); „Oczywiście, że jestem Szwedem. Czuję się Polakiem i Szwedem, i to mi się jedno z drugim nie kłóci” (s. 186); „[Kim jesteś - Szwedką, Polką, Ślązaczką, Żydówką]? [...] wszystkim po trochu. Jakoś nigdy nie miałam potrzeby jednoznacznego określania się. W Szwecji czuję się bardzo dobrze, w Polsce też całkiem nieźle. I tu, i tam mam bliskich mi ludzi" (s. 302).

41 Na zjawisko to naprowadza inspirująca książka poświęcona melodramatowi jako estetycznej praktyce radzenia sobie z niemocą wynikającą z normatywnych tożsamości - zob. .). Goldberg Melodrama. An Aesthetics of Impossibility, Duke University Press, Durham 2016. 
Marcowi emigranci przywożą do Polski więcej niż zabrali ${ }^{42}$ - melodramatyczną taktykę radzenia sobie z tożsamościowymi kłopotami.

Ten nieoczekiwany import trafia w zmieniony klimat polityczny. Retoryka Marcowa - „piąta kolumna”, „wysługiwanie się obcym interesom”, ,prawdziwi Polacy" - powróciła po 2010 roku, choć tym razem uderza w liberałów, feministki, gejów i ekologów. Figury pożyczone z antysemickiej nagonki'68 współtworzą narrację o narodowym cierpieniu, o heroizmie suwerenności i sumują się w postulat legalnej przemocy skierowanej przeciwko "wrogom”. Paradoks czasów polega więc na tym, że dzisiejsza władza konstruuje wizerunek Polski osadzony w estetyce melodramatu. Ale jest to melodramat szczególny: fantazmat niewinnego narodu, na którego cnotę nastają niemoralne siły wewnętrzne i zewnętrzne, ożywia pragnienie nieograniczonej władzy.

Nieoczekiwanie pomarcowe teksty okazują się pomocne w zrozumieniu i podważeniu melodramatycznej gry prowadzonej przez dzisiejsze władze ${ }^{43}$. Identyfikacyjne gry Marcowych emigrantów, którzy przewędrowali pół świata, by z mieszaną tożsamością wrócić do Polski, pozwalają zobaczyć największe niebezpieczeństwo skryte w melodramacie władzy. Dyskurs polityczny narodowej prawicy przedstawia bowiem jako podmiot zraniony samą władzę. Jeśli wzbudzi w odbiorcach żal, to w rezultacie władza powiększy zasięg swojej władzy, a litościwi wyborcy zostaną z politycznej podmiotowości wywłaszczeni. Opowieści Marcowe podpowiadają w tym kontekście jedno: melodramat, który obrazem skrzywdzonej cnoty potrafi wzbudzić gniew, powinien prowadzić do świata równości. Ów świat, wymarzony przez melodramat, poznać można po tym, że gdy gniew opada, równości jest więcej, a nie mniej.

Parafrazuję w ten sposób Grynbergowe motto umieszczone na tablicy na ścianie Dworca Gdańskiego w Warszawie - "Tu więcej zostawili po sobie niż mieli”. 


\section{Abstract}

\section{Przemysław Czapliński}

ADAM MICKIEWICZ UNIVERSITY (POZNAŃ)

March Writing: Two Models of History Processing

Czapliński offers a microsynthesis of Polish literature dealing with the expulsion of Jews from Poland in 1968. Three historical regularities determine this literature's development: 1) the number of texts dealing with March 1968 has steadily grown over the years (signalling that the moment represents a key event and continues to be a central puzzle of modern Polish history); 2) the importance of fiction is on the decline while the literature of testimony (diaries, memoirs, autobiographies, interviews, quasi-documents) are playing an increasingly prominent role; 3 ) at the turn of the ' 80 s and ' 90 s, the dominant narrative pattern changed from the tragic to the melodramatic. Czapliński discusses both models as ways of presenting the birth, decay and (possibly) regeneration of the social bond. The crutial difference between them concerns the possibility of continued Polish-Jewish relations.

\section{Keywords}

March'68, a nationalized pogrom, tragic model, melodramatic model, intertalked history, melodrama of power 